\title{
Benign Epididymal Neoplasm
}

National Cancer Institute

\section{Source}

National Cancer Institute. Benign Epididymal Neoplasm. NCI Thesaurus. Code C3614.

A rare non-metastasizing neoplasm that arises from the epididymis. Representative examples include adenomatoid tumor and leiomyoma. 